\title{
ИЗ ГАЗЕТЫ В ИНТЕРНЕТ-СМИ: ОСОБЕННОСТИ ЖАНРА «ИНТЕРВЬЮ» В СОВРЕМЕННЫХ ОНЛАЙН-ИЗДАНИЯХ
}

\author{
Ерицян Асмик Егишевна \\ Преподаватель Института медиа, рекламы и кино \\ Российско-Армянского Университета
}

Аннотация. В данном исследовании мы рассмотрели структурные, содержательные и типологические особенности жанра «интервью» в интернет-СМИ. Мы также провели параллели между традиционным «газетным» интервью и интервью в онлайн-изданиях, чтобы выявить основные тенденции развития данного популярного жанра журналистики.

Abstract. In this study, we investigate the structural, content and typological features of the interview genre in online media. We also drew parallels between traditional newspaper interviews and interviews in online media to identify the main trends in the development of this popular journalism genre.

Ключевые слова: традиционные СМИ, интернет-СМИ, жанр, интервью.

Keywords: traditional media, online media, genre, interview.

В эпоху развития мультимедийной журналистики, становления кроссмедийных редакций и развития интернет-СМИ интервью по-прежнему остается одним из наиболее популярных и излюбленных жанров журналистики. Интервью пользуется популярностью как среди читателей (аудитории), так и среди журналистов.

Согласно традиционной, академической классификации системы журналистских жанров, интервью относят к информационным, иногда - к аналитическим жанрам. Согласно западной классификации - к комментарийным (мнения). Современное интервью настолько разнообразно, что его становится все труднее вписать в систему традиционных классификаций.

Говоря об интервью, необходимо провести грань между интервью как методом сбора информации и интервью как жанром.

«В первом случае интервью, то есть общение с людьми, - один из трех способов получения информации журналистом. Два других способа - это наблюдение, когда журналист сам является очевидцем события, и работа с документами, где под документом имеется в виду любой материальный носитель, содержащий тексты и изображения. Интервью как метод сбора информации в свою очередь подразделяется на жанровое (для подготовки текста в жанре интервью), расследовательское (для получения информации) и репортажное». [1 с. 62]

Согласно к.ф.н. и автору ряда пособий по журналистике М.М. Лукиной, интервью наиболее популярный метод получения информации у журналистов.

«Интервью - самый распространенный метод получения информации, который применяется журналистами во всех странах мира. Американские исследователи подсчитали, что интервью «съедает» от 80 до 90\% их рабочего времени». [2]

Отметим, что метод интервьюирования необязательно понимать как непосредственный контакт интервьюера и реципиента. Это может быть контакт посредством телефонного разговора или переписки в социальных сетях и т.п.

В основе интервью лежит беседа, акт коммуникации, диалог. Сам диалог как особый вид коммуникации известен еще со времен знаменитых бесед Сократа (метод Сократа) и философских диалогов Платона.

Расцвет интервью как привычного для нас жанра пришелся на XX век. Оно стало одним из самых популярных жанров не только в печатной прессе; после появления радио и телевидения оно уверено заняло свои позиции в теле-и радиожурналистике. Это практически незаменимый жанр в традиционных СМИ. Наиболее привычная для русскоязычной журналистики форма интервью предполагает вопросно-ответную форму повествования. Это классическое, традиционное газетное интервью, которое и по сей день встречается не только в печатной прессе, но и в интернет-СМИ. Прежде чем выделить некоторые жанровые признаки интервью и его виды, попытаемся дать наиболее конкретное, на наш взгляд, определение жанру. Так, согласно определению, которое дает Лукина в учебном пособии «Технологии интервью», интервью - это «межличностное вербальное общение для получения информации и производства нового знания в целях удовлетворения информационных потребностей общества» [2].

Признаки, характерные для жанра газетного интервью

1. целенаправленная беседа, акт коммуникации, который предназначен для распространения в разных видах СМИ;

2. диалогическая природа повествования;

3. вопросно-ответный стиль повествования (в классическом интервью); 
4. интервьюируемый - общественно-значимая фигура (или компетентное лицо по теме экспертного интервью);

5. публичный характер разговора;

6. двуадресность [2] ${ }^{-}$предназначенность для информирования и воздействия не только на участников диалога, но и на аудиторию.

Герои современных, мультимедийных интервью - не всегда известные персоны. Ими все чаще становятся обыкновенные люди со своими истории. Основным признаком жанра остается целенаправленный, публичный акт коммуникации между интервьюером и интервьюируемым (интервьюируемыми) для распространения в СМИ. Без этого признака, который является ядром интервью, жанр не сможет существовать. А вопрос его оформления - в прикладной журналистике постепенно отходит на второй план.

Таким образом, современное интервью разнообразно, а его противоположные полюсы являются объектами для споров и разногласий: «при этом на одном полюсе находится интервью-монолог, где количество вопросов журналиста сведено к минимуму (иногда их вообще нет), на другом полюсе - беседа, когда журналист не только задает вопросы, но и сам выступает с пространными рассуждениями».[1 с.62]

В зависимости от целей и характера беседы интервью в академической журналистике принято выделять на определенные типы: у разных авторов можно встретить разную типологию жанра.

Мы обобщили характеристики различных типов интервью у разных авторов (в основе классификации Тертычного, Колесниченко и Лукиной) и кратко изложили их специфические особенности.

Информационное интервью. Подобный тип интервью больше относится к методу сбора информации для новостей, репортажа и других жанров, а в качестве отдельного жанра в современных интернет-СМИ практически не встречается. Интервьюер делает акценты на вопросы что? где? когда? Стилистика отличается краткостью предложений и лексической простотой и ясностью, без каких-либо средств выразительности языка. Основная цель метода - узнать как можно больше подробностей и деталей о событии или происшествии и оперативно передать информацию аудитории.

Аналитическое (экспертное, предметное) интервью. Содержательной основой для подобного интервью является анализ фактов и явлений от компетентного лица. Оно отвечает на вопросы: почему? каким образом? что это значит? В электронных изданиях наиболее часто встречается в специализированных, аналитических изданиях. В новостных ресурсах как целостный жанр в вопросно-ответной форме встречается не так часто; обычно экспертное интервью разбивают на небольшие комментарии или новостные заметки (мнения).

Портретное, (индивидуальное, личностное) интервью. Содержательной основой для подобного интервью является не информация или событие, а человек и его личностные качества. Допускается использование средств выразительности языка, в частности, таких речевых конструкций, позволяющих воздействовать на интервьюируемого. Цель подобного интервью - показать внутренний мир героя интервью, раскрыть для читателя его качества, «очеловечить гламурный образ» (Колесниченко «Практическая журналистика). Портретное интервью встречается часто в электронных СМИ как в авторитетных изданиях, так и в СМИ развлекательного характера. Является излюбленным видом жанра в т.н. желтой прессе, когда речь идет о звездах шоу-бизнеса.

Портретное интервью - один из самых востребованных аудиторией типов интервью в интернет-СМИ. Примером подобного интервью является интервью российского издания «РИА Новости» с писательницей Наринэ Абгарян. В нем она отвечает на вопросы, связанные с ее биографией, взглядами на жизнь, историей успеха. Отметим, что это типичные вопросы для портретного интервью, благодаря которым раскрываются интересные факты из жизни интервьюера, его внутренний мир и личностные качества. Приведем в качестве примера отрывок из интервью с Наринэ Абгарян:

«Вы всегда хотели стать писателем или это стало для вас неожиданностью?

Нет, в детстве я мечтала быть продавцом мороженого! Потом выучилась на преподавателя русского языка и литературы, но в школе, к сожалению, не преподавала. А в Москву приехала за вторым высшим образованием и очень долго себя здесь искала. Ни в одной профессии у меня ничего не складывалось, и было четкое ощущение, что я вообще никчемный человек. В результате я переучилась на бухгалтера и стала самым-самым неудачливым бухгалтером Москвы.

Писателем я стала от безысходности: просто завела себе страницу в "Живом журнале" и начала публиковать там свои истории. Меня заметило издательство (я бы сама никогда не рискнула отправить то, что пишу), и вот так, совершенно случайно, в 39 лет я проснулась писателем». [3]

Успех подобных материалов зависит от того, сможет ли автор своими вопросами и доверительной обстановкой вокруг добиться максимальной искренности интервьюера (если речь, конечно, не идет об интервью-разоблачении). Очень часто портретное интервью похоже на непринужденную беседу. Так, подобные материалы иногда выделяют в отдельный жанр или формат - формат беседы. Жанр портретного интервью, как мы уже отметили, очень популярен в различных глянцевых изданиях, где основными героями являются звезды шоу-бизнеса. 
Портретное интервью дают также многие политики, официальные лица, бизнесмены с целью «смягчить» свой образ и казаться ближе к общественности. Не всегда героями портретного интервью становятся известные люди. Все чаще русскоязычные СМИ прибегают к поиску героев из жизни для своих материалов.

Проанализировав современное интервью в интернет-СМИ, мы пришли к следующим выводам:

С одной стороны, интервью как целостный и классический жанр журналистики с вопросно-ответной формой повествования по-прежнему встречается как в газетной, так и в интернет-журналистике. Чаще всего в такой форме встречается информационно-аналитическое интервью с официальными лицами, экспертами, политиками.

С другой стороны, метод интервью используется в других жанрах журналистики, особенно в таких формах, которые начинаются приобретать черты различных жанров (личные истории, правила жизни, интервьюпортреты). В итоге, эти жанры можно рассматривать как виды современного интервью, так и как отдельные, новые жанры журналистики.

Таким образом, интервью в современных интернет-СМИ встречается как в чистом виде (конечно, с использованием мультимедиа и других возможностей социальных медиа), так и в качестве метода сбора информации - так, оно становятся базой для формирования новых жанров журналистики.

\section{ЛИТЕРАТУРА}

[1] Колесниченко А.В. Практическая журналистика - М.: МГУ, 2013.

[2] Лукина М.M. Технология интервью. М.: Аспект-пресс, 2012, [Электронный ресурс] - URL: http://evartist.narod.ru/text5/36.htm (дата обращения 14.12.2021).

[3] Наринэ Абгарян: нужно стараться не отождествлять себя с успехом и с книгой. РИА Новости, [Электронный ресурс] - URL: https://ria.ru/interview/20180320/1516763415.html (дата обращения 14.12.2021). 